Canadian University Music Review

Revue de musique des universités canadiennes

\title{
Kevin Bazzana. Glenn Gould: The Performer in the Work. Oxford: Clarendon Press, 1997. xxii, 297 pp. ISBN 0-19-816656-7 (hardcover)
}

\section{Allan Hepburn}

Volume 20, numéro 2, 2000

URI : https://id.erudit.org/iderudit/1014461ar

DOI : https://doi.org/10.7202/1014461ar

Aller au sommaire du numéro

Éditeur(s)

Canadian University Music Society / Société de musique des universités canadiennes

ISSN

0710-0353 (imprimé)

2291-2436 (numérique)

Découvrir la revue

Citer ce compte rendu

Hepburn, A. (2000). Compte rendu de [Kevin Bazzana. Glenn Gould: The Performer in the Work. Oxford: Clarendon Press, 1997. xxii, 297 pp. ISBN 0-19-816656-7 (hardcover)]. Canadian University Music Review / Revue de musique des universités canadiennes, 20(2), 99-102.

https://doi.org/10.7202/1014461ar

All Rights Reserved (c Canadian University Music Society / Société de musique des universités canadiennes, 2000
Ce document est protégé par la loi sur le droit d'auteur. L’utilisation des services d'Érudit (y compris la reproduction) est assujettie à sa politique d'utilisation que vous pouvez consulter en ligne.

https://apropos.erudit.org/fr/usagers/politique-dutilisation/ 
tsunami (much of it in the wake of the revelations about Paul De Man). Let us hope that with Klumpenhouwer's contribution we have the first tremors, and that these last paragraphs become the opening of a new work.

The potential readership for the volume stretches from the undergraduate theory seminar numbed by the recent spate of soporific surveys of the field, like Nicholas Cook's A Guide to Musical Analysis, to the accomplished scholar for whom the interdisciplinary vistas opened by these essays should prove refreshing. No doubt theory will continue to be taught as it has-the cultivation of extremely close reading skills-for many years to come, although, with burgeoning undergraduate populations and a decimation of the professorial ranks, just how long this can be sustained is a moot point. No doubt, accomplished scholars will also be able to ignore these developments so as to tread theoretical paths well worn since the putatively positivist 1960s, although, given the interdisciplinary breakdown of insular departmental mandates, just how long the university can continue to sustain scholars with such a fine focus is similarly moot. Indifference apart, to anyone with a modicum of adventure, the present volume should prove a tonic.

Murray Dineen

Kevin Bazzana. Glenn Gould: The Performer in the Work. Oxford: Clarendon Press, 1997. xxii, 297 pp. ISBN 0-19-816656-7 (hardcover).

Glenn Gould haunts us in many guises. Gould the pianist. Gould in thirty-two short films by François Girard. Gould-inspired ballets choreographed by James Kudelka. The Glenn Gould Studio inside the CBC headquarters in Toronto. Glenn Gould the professional performance school at the Royal Conservatory of Music. Gould the Foundation. Gould the bronze statue lolling on a bench outside the Glenn Gould Studio. Gould the conference. Glenn Gould the twiceyearly journal. Gould the maker of documentaries. Glenn the hit play by David Young. Gould the pill-popper. Gould the weirdo wearing wool gloves in summer. Gould the complete recordings on SONY Classical. Gould's Yamaha piano squatting like a massive black coffin in the lobby of Roy Thomson Hall, untouched, sacrosanct. Gould the icon. Gould the iconoclast.

Kevin Bazzana augments the trove of Gouldiana with an analysis of the pianist's performance objectives and practices. Bazzana begins by discussing Gould's projection of "idealism" in music, his belief in the performer as a cocreator of a composition, and performance as a critique of previous interpretations. When Gould revises compositions to emphasize structural clarity, he does so to enhance music that exists abstractly in the mind before it exists acoustically in the world. Bazzana applies such ideals to Gould's pianistic praxis: his profound sense of time; his rhythmic exactitude; his control of dynamics, especially in the pianissimo to mezzo-forte range; his détaché touch. This study is amply and expertly detailed and includes a CD sampler correlated to the text. Bazzana draws parallels between early and late recordings, and traces evolutions in Gould's thinking about performance over time.

Bazzana argues that Gould's approach to performance "raises basic issues 
in aesthetics" (p. 12) and that often his recorded performances, more so than his live ones, provide an "exegesis" (p. 85) of music rather than a cathartic release. Performance challenges auditors to rethink previously heard repertory. Bazzana notes that "it is difficult not to despair when confronted with yet one more performance of a familiar piece that simply reminds us how the music 'goes.' Gould here tapped into a curious fact of his historical situation. It is indeed ironic that it is in post-war musical life, in the era of recording, that fidelity to the work is such a prevailing principle" (p. 78).

One of the most intriguing questions of this book concerns Gould's humour. Bazzana notes, quite justly, that Gould exaggerates ornaments in Beethoven's Appassionata sonata, making them grotesque rather than supple and heroic. More cheekily, Gould burlesques Mozart's piano sonatas, bringing forth their comic potential - to the outrage of those listeners who like their Mozart straight. Citing Henri Bergson's Laughter to make his case, Bazzana sketches out an aesthetic problem of comic intentionality in music. Does humour exist in music as an artistic invention (pratfalls and gags penned by Mozart) or does humour originate in the performance of music (pratfalls and gags imposed by Gould)? Are some of Gould's late recordings a parody of his early ones? The question of comedy applies to other repertory-repertory that Gould found uncongenial-such as Schumann's Piano Sonata in F-sharp Minor, op. 11, where the direction to play "alla burla, ma pomposo" calls attention to grotesquery in the score. It would be worthwhile to consider in this context the acerbic or refined comedy in Ginastera's "Danza del gaucho matrero," Ravel's parodies of Haydn and an "antique" minuet, Prokofiev's Sarcasms, or Bartók's "From the Diary of a Fly." If Gould were sincerely interested in exploiting the latent comedy in music, why did he avoid such repertory? Bergson emphasizes "mechanical inelasticity" of the body a primary source of humour. Gould's crouching, tension-producing position at the piano parodies the act of piano-playing itself, not just of the limitations of flashy virtuosity, which he deplored.

Gould, ultimately, compels listening by the force of personality, and he is, in this regard, a modernist egomaniac absorbed in problems of personality. T. S. Eliot sniffily declares in his 1919 essay, "Tradition and the Individual Talent," that "only those who have personality and emotions know what it means to want to escape from these things." ${ }^{1}$ Eliot echoes Oscar Wilde's epigram from The Picture of Dorian Gray, "The highest, as the lowest, form of criticism is a mode of autobiography."2 Personality and emotion emerge as "problems" or "cases" in the twentieth century that one wishes to flee. Gould escapes from personality through abstraction and form. Yet he hums in the background while playing and makes his pianistic style so distinctive that no audiophile would mistake a Gould recording for any other. His insistence on treating all keyboard music rationally, played as simulacra of Bach and Schoenberg, limits his interpretations and the scope of his intellectual grasp. By adjusting "individual

\footnotetext{
${ }^{1}$ T. S. Eliot, Selected Essays (Orlando: Harcourt Brace Jovanovich, 1960), 11.

2 Oscar Wilde, "Preface" to The Picture of Dorian Gray, ed. Peter Ackroyd (Harmondsworth: Penguin, 1985), 21.
} 
tempos for the sake of the consistency of an overall conception" (p. 160) in the movements of a Bach dance suite, for example, Gould emphasizes form-the work is unified, whole, minutely interrelated in its parts-rather than allowing the dances to relate to bodies in motion, or an aesthetics of fragmentation, or a politics of internationalism that brings together French, Italian, English, and German dances. Bazzana need not judge Gould's limitations and assets as a performer; however, it would be useful to consider why Gould's aesthetics bring him to so many dead ends in terms of repertory, concert appearances, and sonority. Many people admire Gould, but few care to imitate him.

Several flaws mar this book. Noticeably, it repeats itself. For instance, the reader learns on many occasions that Gould was indebted to Rosalyn Tureck's Bach interpretations. Bazzana is to be admired for spending so much time going over archival materials and for lavishing so much attention on details of recording. He is not to be admired, however, for saying so many times that Gould "flagged" Adorno's comments (pp. 36 n., 65, 90, 108, 218). Almost as soon as Adorno's name appears, the verb "flagged" leaps into place. Sometimes analysis does not go far enough. Schoenberg's idea of "developing variation" as a theoretical tool for showing motivic unity affects Gould's thinking about structure; yet the connection between developing variation and repression or ideology or psychology or technology, or some principle that is not itself Gouldian, never materializes. Sometimes theory and analysis do not integrate well. Although Gould's acquaintance with McLuhan is mentioned, the connections between McLuhan's ideas of technology and Gould's manipulations of technology never get thoughtfully elaborated. Bazzana musters literary theoryUmberto Eco, Roland Barthes, Jean-François Lyotard-to assist his interpretation, but the appearance of such heavy-hitters gets neutralized by Gould's own formalist assumptions. Contemporary theories of performativity might be more appropriately brought to bear on questions of performance. Given that a great deal of Gouldiana is already before readers and listeners, one craves more analysis, more risk, more judgment from a book about Gould as a performer.

One could, for instance, consider Gould in the virtuoso tradition as an icon of pianistic decadence: self-obsessed, withdrawn, mannerist. Even his renunciation of virtuosity serves the cult of his genius. Yet Gould-what we see of him on television tapes and hear of him in his recordings-acts out the pathologies of performance. In The Society of the Spectacle, Guy Debord declares that "the individual who in the service of the spectacle is placed in stardom's spotlight is in fact the opposite of an individual, and as clearly the enemy of the individual in himself as of the individual in others." 3 According to Debord, the icon is inhuman. The icon expresses desires that the public cannot avow as its own. The icon concentrates and re-exerts those desires through performance. The icon is therefore both alien to the public and adored by the public as a familiar Other. Debarred from individuality, the star turns enemy to his own personality and self-destructs. The icon belongs to, is a phantasmatic projection of, his fans, nothing

\footnotetext{
${ }^{3}$ Guy Debord, The Society of the Spectacle, trans. Donald Nicholson-Smith (1968; New York: Zone Books, 1995), 39.
} 
more. Glenn Gould, by renouncing the stage for the recording studio while still in his thirties, provides an antidote to Debord's idea of the icon as the embodiment of fans' wishes and the incarnation of mass fantasies. Gould, notorious recluse, never lost his individuality. His idiosyncratic recordings of Mozart, Beethoven, and other composers are a sustained critique of the musical culture of virtuosos and exhibitionism. What happens when you separate a virtuoso pianist from his status as an icon? You begin to see the tension between his performance and his iconic status. Gould is a virtuoso malgré lui. He is an icon who critiques fans' adherence to star systems. He is a performer who makes music serve an ideal by alienating listeners from their fantasies about repertory. Whatever image of himself and of music that he wished to project, Gould also emanated an image of neurotic disablement and glory, even posthumous glory, that contradicts the stringent idealism that he set out to perform.

Allan Hepburn

Fenner Douglass. Cavaillé-Coll and the French Romantic Tradition. New Haven and London: Yale University Press, 1999. xiii, 235 pp. ISBN 0-300-07114-0 (hardcover).

"The Revolution," asserts Fenner Douglass, "left French organs in ruins. Had the Reign of Terror (1792-94) continued to the end of the 18th century, it is likely that the art of organ building would have vanished from France altogether" (p. 1). With those ringing words Douglass begins his story of Aristide Cavaille-Coll (1811-99), whose career would rise from the ashes of the early nineteenth century, and who would go on to produce organs unlike any heard before. Though their superlative tonal beauty and finish would in themselves qualify Cavaillé-Coll as one of the four or five greatest organ builders of all time, more significant still is the way in which his organs have inspired a still flourishing tradition of composition and performance. Franck, Widor, Vierne, Dupré, Duruflé, and Messiaen responded to the rich sounds of Cavaillé-Coll's instruments by producing a body of literature for organ surpassed only by that of the North German school of Buxtehude and Bach. In the present volume, Douglass examines the first three decades of Cavaillé-Coll's long career in an attempt to show how so influential a figure could have arisen from so unpromising a cultural and historical background.

Much of this, according to Douglass, was sheer luck, though that luck attached itself to a man of genius, perspicacity, and winsome personal qualities. In chapter 2 Douglass points out that Cavaillé-Coll's rise to prominence corresponded fortuitously with the coming to France of rail travel, which permitted him to move quickly around the country, as demanded by his contracts for provincial cathedrals and churches. Increasing mechanization meant that the old craft of organ building, like the manufacture of pianos, had become an industry, and Cavaillé-Coll took full advantage of these opportunities. Even so, fortune smiled upon him with unusually enduring warmth. It was Rossini who, after hearing an instrument built in Toulouse by Cavaillé-Coll, urged the twenty- 